\title{
Implementation Research: New Imperatives and Opportunities in Global Health
}

\author{
Authors: \\ Sally Theobald, $\mathrm{PhD}^{1}$, Neal Brandes, $\mathrm{MHS}^{2}$, Margaret Gyapong, $\mathrm{PhD}^{3}$, Sameh El-Saharty, MD, \\ $\mathrm{MPH}^{4}$, Enola Proctor, $\mathrm{PhD}^{5}$, Theresa Diaz, MD MPH${ }^{6}$, Samuel Wanji, $\mathrm{PhD}^{7}$, Soraya Elloker, \\ $\mathrm{MN}^{8}$, Joanna Raven, $\mathrm{PhD}^{1}$, Helen Elsey, $\mathrm{PhD}^{9}$, Sushil Bharal, $\mathrm{PhD}^{10}$, David Pelletier, $\mathrm{PhD}^{11}$, \\ David H Peters, DrPH ${ }^{12}$
}

\author{
Affiliations: \\ 1 Department of International Public Health, Liverpool School of Tropical Medicine, \\ Liverpool, UK. \\ 2 USAID, Washington, DC, USA. \\ 3 University of Health and Allied Sciences, Ho, Ghana. \\ 4 The World Bank, Middle East and North Africa Region, Human Development Sector, \\ Washington, DC 20433, USA \\ 5 Brown School of Social Work, Washington University in St. \\ Louis, St. Louis, MO, USA \\ 6 Department of Maternal, Newborn, Child and Adolescent Health (MCA) World Health \\ Organization 20 Avenue Appia 1211 Geneva 27. Switzerland \\ 7 Department of Microbiology and Parasitology, the University of Buea, Cameroon \\ 8 Sub-District Health Manager, City of Cape Town, South Africa \\ 9 Nuffield Centre for International Health and Development, University of Leeds, Leeds, UK. \\ 10 HERD International, Kathmandhu, Nepal \\ ${ }^{11}$ Cornell University, Division of Nutritional Sciences, Program in International Nutrition, \\ Ithaca, NY, USA. \\ ${ }^{12}$ Johns Hopkins University Bloomberg School of Public Health, Department of International \\ Health, Baltimore, MD, USA.
}

\section{Corresponding Author:}

Professor Sally Theobald

Department of International Public Health, Liverpool School of Tropical Medicine, Liverpool, UK Email: sally.theobald@lstmed.ac.uk

Tel: +441517053197

\author{
Word Count (Main Text): 5,951 \\ Word Count (Abstract): 327 \\ Keywords: 8 \\ Tables:3 \\ Panels: 4 \\ Figures: 0 \\ References: 80
}

Key words: implementation research, implementation science, delivery science, program science, health systems, impact, case studies 


\title{
Implementation Research: New Imperatives and Opportunities in Global Health
}

\begin{abstract}
Implementation research is important in global health to address the challenges of the know-do gap in real world settings, and the practicalities of achieving national and global health goals. Implementation research is an integrated concept linking research and practice to accelerate the development and delivery of public health approaches. It involves the creation and application of knowledge to improve the implementation of health policies, programmes, and practices. It uses multiple disciplines and methods, and emphasises partnerships between community members, implementers, researchers and policy makers. Implementation research focuses on practical approaches to improve implementation; to enhance equity, efficiency, scale up and sustainability, and ultimately to improve people's health. There is growing interest in the principles of implementation research, and a range of perspectives on its purposes and appropriate methods.
\end{abstract} However, there have been limited efforts to systematically document and review learning from the practice of implementation research across different countries and technical areas. Drawing on an expert review process, this paper presents purposively selected case studies to illustrate the essential characteristics of implementation research and its application in low and middleincome countries (LMICs). The case studies are organized in four categories related to the purposes for using implementation research: impacting people's health, informing policy design and implementation, improving health service delivery, and empowering communities and beneficiaries. Common characteristics of these case studies are the focus on addressing implementation problems, ensuring a partnership approach to the co-creation of solutions, including using tacit knowledge, and commitment of key stakeholders to a pathway towards impact. The case studies reveal the complex adaptive nature of health systems, emphasize the importance of understanding context, and highlight the role of multidisciplinary, rigorous and adaptive processes which allow for course correction to ensure interventions have an impact. This 
paper is part of a call to action to increase the use of implementation research in global health, build the field, and accelerate efforts to bridge the gap between research, policy, and practice to improve health outcomes.

Funding: Funding Alliance for Health Policy and Systems Research, World Bank and USAID (by the Health Research Challenge for Impact ( $\mathrm{HRCl})$ Project with a Leader with Associates (LWA) Cooperative Agreement (\#GHS-A-00-09-00004-00) to Johns Hopkins University, and the Translating Research into Action project funded under cooperative agreement GHS-A-00-0900015-00 with University Research Corporation).

The views expressed are those of the authors and not necessarily of that of USAID, World Bank, or World Health Organization 
Implementation Research: New Imperatives and Opportunities in Global Health

\section{Panel 1: Key messages}

1. Implementation research offers a way to understand and address implementation challenges and make a positive impact on people's health by contributing to building stronger and more responsive health systems within the realities of specific contexts.

2. Implementation research can lead to positive health outcomes, inform policy design, improve health management and service delivery, and support and empower communities and beneficiaries.

3. Implementation research uses multidisciplinary approaches and a range of empirical and systematic methods to document, analyse and address key health problems and test technical health interventions as well as contextually tailored innovative strategies within the foundations of local context.

4. Implementation research can be used to evaluate the feasibility, adoption, and acceptance of interventions, as well as coverage (particularly in reaching disadvantaged groups), quality, equity, efficiency, scale, and sustainability.

5. Implementation research involves an approach to doing research that fosters ownership, collaboration, and influence; policy-makers, implementers, communities, and researchers should work together throughout the research and implementation processes to build trusting partnerships and the co-production of knowledge.

6. Implementation research involves some key trade-offs to consider: (i) rigor versus usefulness of the research; (ii) fidelity versus adaptation of an implementation component; (iii) embedded versus externally objective approaches; (iv) seeking generalizable knowledge versus context-specific problem-solving; (v) incentives versus disincentives for researchers and implementing agencies.

\section{Introduction}

In global health, many specific interventions have been shown that they can be effective at low cost in relatively controlled environments, in short-term studies, or on small scales. ${ }^{1}$ But building strong and responsive health systems that promote health and well-being through sustainable strategies that work on a significant scale remains a critical challenge, particularly in low and middle-income countries (LMICs).

Internationally, the need for implementation research could not be greater or timelier. The Sustainable Development Goals (SDGs) and national commitments for universal health coverage require effective implementation of proven interventions to improve health outcomes and ensure that no one is left behind. Implementation research provides a set of approaches, methods, tools 
and ways of bridging research and practice to address these issues. Implementation research offers a renewed focus on how to accelerate the development and delivery of services that improve and sustain health and well-being for all, including the most disadvantaged.

The aim of this paper is to present the characteristics that define implementation research and their application in global health through case studies. We demonstrate how evidence can inform practice, and the potential of implementation research to make an impact across different contexts and implementation problems using a range of research methods in LMICs. The case studies highlight contexts where there are heightened challenges to achieving the Sustainable Development Goals and universal health coverage.

\section{Panel 2: Researchers are from Venus, policy-makers are from Mars}

Policy-makers, funders, implementers, researchers, and community members each view problems differently. Wendy Graham of Aberdeen University famously characterized it as, "researchers are from Venus and policy-makers are from Mars". ${ }^{2}$ She, however, wisely recruited Dr. Sam Adjei for a time to advise her. Sam, who died in $2016^{3}$, had an illustrious career bridging these two worlds and was an inspiring champion of the potential of an implementation research vision in Ghana and internationally. He set up the The Ghana National Health Research Unit (HRU) to promote, institutionalize, coordinate and conduct health systems and operational research focused on the utilization of research results. Today, it has transformed into a Division in the Ghana Health Service with three vibrant internationally recognized field research centres, ensuring that health research is responsive to country needs and priorities.

\section{Defining implementation research}

Implementation research builds on a number of research traditions, and each of these research traditions has developed its own set of core disciplines, primary audiences for their research, and typical sets of research questions (Table 1). In part due to the "invisible colleges" that have formed from the different traditions, the field of implementation research in health has yielded considerable debate over its scope, theories and methods, terminology, and areas of emphasis (see Panel 3). Whereas we recognize the value of these debates, we use a broader and more 
inclusive definition of implementation research that emphasises the unifying focus of the varied histories and disciplines: "the scientific inquiry into questions concerning implementation—the act of carrying an intention into effect, which in health research can be policies, programmes, or individual practices." " Implementation research is about using systematic research methods to improve policies and program delivery, and knowledge translation, preferably through real-time application of knowledge gained into real-world programmatic change. ${ }^{5}$ It addresses a range of implementation challenges, including inefficient or inequitable use of resources, inequity in coverage or supply and demand barriers to scaling-up and sustainability. ${ }^{5}$ Implementation research is a convergence of approaches better known in high income countries in the fields of management, education, social and health services. ${ }^{4,6,7}$ Implementation research emphasizes attention and dynamic adaptation to local context, stakeholders, local care resources, and end user engagement in understanding how and why change processes work. ${ }^{8}$

Table 1: Implementation Research Traditions and their Typical Research Targets, Research Questions, and Initial Core Disciplines (from Peters et al, 20134)

\begin{tabular}{|c|c|c|c|}
\hline $\begin{array}{l}\text { Implementation } \\
\text { Research } \\
\text { Tradition }\end{array}$ & $\begin{array}{l}\text { Typical primary } \\
\text { audience for } \\
\text { research }\end{array}$ & $\begin{array}{l}\text { Typical research } \\
\text { questions }\end{array}$ & $\begin{array}{l}\text { Core disciplines at } \\
\text { origin }\end{array}$ \\
\hline $\begin{array}{l}\text { Management } \\
\text { improvement }\end{array}$ & $\begin{array}{l}\text { Managers and teams } \\
\text { using improvement } \\
\text { strategies }\end{array}$ & $\begin{array}{l}\text { How are the right services } \\
\text { delivered to the right } \\
\text { clients while meeting the } \\
\text { right standards for } \\
\text { quality? }\end{array}$ & $\begin{array}{l}\text { Engineering, } \\
\text { management }\end{array}$ \\
\hline $\begin{array}{l}\text { Operational } \\
\text { research }\end{array}$ & $\begin{array}{l}\text { Executive decision- } \\
\text { makers (executive } \\
\text { bodies, policy- } \\
\text { makers) }\end{array}$ & $\begin{array}{l}\text { Which solution provides } \\
\text { the most rational basis for } \\
\text { a decision concerning the } \\
\text { optimal performance of a } \\
\text { system? }\end{array}$ & $\begin{array}{l}\text { Mathematics, } \\
\text { engineering, } \\
\text { management }\end{array}$ \\
\hline $\begin{array}{l}\text { Policy } \\
\text { implementation }\end{array}$ & $\begin{array}{l}\text { Top down: Central } \\
\text { level policy-makers } \\
\text { Bottom up: "Street } \\
\text { level" programme } \\
\text { implementers }\end{array}$ & $\begin{array}{l}\text { Top down: How was a } \\
\text { policy/programme } \\
\text { implemented, and what } \\
\text { contributed to its } \\
\text { outcomes? } \\
\text { Bottom up: Which actors } \\
\text { are involved in } \\
\text { programme delivery in } \\
\text { specific locations, how do } \\
\text { they understand the } \\
\text { problem of } \\
\text { implementation, and what }\end{array}$ & $\begin{array}{l}\text { Political science, } \\
\text { public policy, public } \\
\text { administration }\end{array}$ \\
\hline
\end{tabular}




\begin{tabular}{|c|c|c|c|}
\hline $\begin{array}{l}\text { Implementation } \\
\text { Research } \\
\text { Tradition }\end{array}$ & $\begin{array}{l}\text { Typical primary } \\
\text { audience for } \\
\text { research }\end{array}$ & $\begin{array}{l}\text { Typical research } \\
\text { questions }\end{array}$ & $\begin{array}{l}\text { Core disciplines at } \\
\text { origin }\end{array}$ \\
\hline & & $\begin{array}{l}\text { influences their } \\
\text { behaviour? }\end{array}$ & \\
\hline $\begin{array}{l}\text { Programme } \\
\text { evaluation }\end{array}$ & $\begin{array}{l}\text { Stakeholders of a } \\
\text { programme (e.g. } \\
\text { funders, } \\
\text { implementers, and/or } \\
\text { intended beneficiary) }\end{array}$ & $\begin{array}{l}\text { Is the programme } \\
\text { producing intended } \\
\text { effects? How is it } \\
\text { designed, implemented, } \\
\text { used, fit to context and } \\
\text { problems, with what } \\
\text { results and programme } \\
\text { changes? }\end{array}$ & $\begin{array}{l}\text { Sociology, public } \\
\text { policy, economics, } \\
\text { social work, } \\
\text { psychology }\end{array}$ \\
\hline $\begin{array}{l}\text { Dissemination and } \\
\text { implementation of } \\
\text { evidence-based } \\
\text { medicine }\end{array}$ & $\begin{array}{l}\text { Practitioners, health } \\
\text { organization } \\
\text { managers, policy- } \\
\text { makers not using } \\
\text { evidence-based } \\
\text { interventions }\end{array}$ & $\begin{array}{l}\text { What promotes the } \\
\text { integration of research } \\
\text { findings and evidence on } \\
\text { interventions into } \\
\text { healthcare practice? }\end{array}$ & $\begin{array}{l}\text { Behaviour change } \\
\text { (psychology, } \\
\text { sociology, education), } \\
\text { epidemiology }\end{array}$ \\
\hline $\begin{array}{l}\text { Participatory action } \\
\text { research }\end{array}$ & $\begin{array}{l}\text { Research } \\
\text { participants, } \\
\text { community members }\end{array}$ & $\begin{array}{l}\text { How can we (community } \\
\text { members as research } \\
\text { participants) learn and be } \\
\text { empowered to take } \\
\text { action? }\end{array}$ & $\begin{array}{l}\text { Non-disciplinary or } \\
\text { trans-disciplinary, but } \\
\text { largely influenced by } \\
\text { social psychology, } \\
\text { education, and } \\
\text { anthropology }\end{array}$ \\
\hline
\end{tabular}

\section{Panel 3: Implementation research: What's in a name?}

The divergent histories and disciplines that have addressed implementation questions continue to stimulate much debate over terminology, theory, and methods. For many who are largely interested in effective implementation, it is often difficult to distinguish whether these debates signal any progress in understanding as the science advances, or are simply the territorial markings of different research "tribes" or "invisible colleges". 2

Although it is one of the more recent research traditions, the emergence of evidence-based medicine has spawned a branch of implementation science that now dominates the clinical literature, defining implementation science as the "scientific study of methods to promote the systematic uptake of research findings and other evidence-based practices into routine practice, and, hence, to improve the quality and effectiveness of health services and care." ${ }^{3}$ Within this tradition, an attempt was made to provide consistent definitions for the field, which the authors called "Dissemination \& Implementation Research". 9 Yet by 2015, a literature review of definitions for implementation science that just focused on HIV/AIDS identified 73 different definitions for the term, mostly from this same tradition. ${ }^{10}$ The results prompted the authors to expand the definition of implementation science as a "multidisciplinary specialty that seeks generalisable knowledge about the behaviour of stakeholders, organisations, communities, and individuals in order to understand the scale of, reasons for, and strategies to close the gap between evidence and routine practice for health in real-world contexts". ${ }^{10}$

A comparison of the different strands of research traditions that study implementation (e.g. operational research, scientific management, policy and programme evaluation, participatory action research, in addition to the dissemination of evidence-based practices) suggests they have much in common with the 
expanded definition, though some fields have a broader scope (e.g. to include policy and programmes beyond "practice") or include specific methods, since "evidence" has different connotations in different fields. ${ }^{4}$ Other research traditions do not focus solely on generalisable knowledge, but also on the use of knowledge, or the interface of knowledge and action. Global health discussions have highlighted the importance of multi-disciplinarity, collaboration, real-world settings, problems of scale and sustainability, and the bi-directional links between practice and evidence, ${ }^{5}$ which motivates the use of terms such as "delivery science"" 11 and "programme science". ${ }^{12}$

Although the terms "science" and "research" are often used interchangeably, research is critical part of science, and involves the use of scientific methods to gather and analyse data to answer questions. Yet the term "research" can also be controversial to some organisations, and has practical consequences. For example, some Universities may consider activities to be research only when the work is intended for publication (or more broadly to produce generalisable knowledge), or when there is a specific sponsor for the activity. This may distinguish formal research from problem-solving activities, even when they use the same research methods. Similarly, some funded projects are categorized as quality improvement or public health practice rather than more traditional human subjects research. This may result in different types of ethical review of the protocols, depending on how the activity is classified.

Conducting research is also problematic for agencies that do not have a research mandate; in global health, this could include GAVI, UNICEF, The Global Fund, and many public health agencies. Because they often need robust information about their programmes and are often expected to use robust monitoring and evaluation, they classify their activities as non-research activities, sometimes as monitoring and evaluation, learning, or occasionally as operations research. They also use different funding mechanisms for these activities. We propose that all these activities may be considered implementation research when robust scientific methods are used to answer questions related to implementation. This still means there is a need to carefully ask relevant questions and apply appropriate theories and methods to the problem.

Although we do not advocate for a single theory among the many theoretical frameworks in the field, there are some particularly useful meta-frameworks that bridge theories and help to identify more specific theories and methods that can fit a particular question or context. These include the Consolidated Framework for Implementation Research, ${ }^{13}$ the National (US) Implementation Research Network's Active Implementation Frameworks (Usable interventions, Implementation stages, Implementation drivers, Implementation teams, and Improvement cycles), ${ }^{14}$ a synthesis of frameworks on implementation processes, ${ }^{15}$ and an analysis of models according to a socioecological framework to help identify and select relevant frameworks. ${ }^{16}$ There are also many helpful handbooks, including WHO's introductory Implementation Research Guide,${ }^{17}$ and the STaRI statement on how to report implementation research. ${ }^{18}$

In global health, much of the effort has been placed on building bridges: across knowledge producers, consumers, and beneficiaries; policy-makers, funders, programme implementers, and analysts; and across traditions of research, monitoring and evaluation. ${ }^{5}$ Learning from formally designed research projects, adapting robust research methods for local problem-solving and monitoring, and approaches to systematize tacit knowledge and experience are all used to "make more informed decisions and produce consistent results on the ground". ${ }^{19}$ Ultimately implementation research is intended to improve people's health through more informed policies, 
strengthened service delivery, empowered communities, more capable programme implementers and health providers, and more informed policy-makers.

\section{Methods to synthesise learning on implementation research}

Multiple case studies of implementation research projects in differing LMIC contexts were selected and analysed within a framework of core characteristics of implementation research.

The framework and selection of case studies in this paper was informed by a set of five structured and consultative international meetings held between 2012 and 2016 (see panel 4) bringing together researchers, donors and policy-makers to identify problems and opportunities related to implementation research, build consensus in describing the field, showcase useful examples and develop priorities for action.

The case studies included here were purposively selected through a process of inclusive debate enabled by these meetings (Panel 4) to illustrate common characteristics of implementation research (Table 2) and to show its relevance in a range of geographical and political contexts, implementation topics and questions, scale of implementation (from continent wide to national to local), disciplines and methodologies and types of impact. Impact types include: i) on people's health; ii) on policy design and implementation; iii) improving health management and service delivery and iv) supporting and empowering communities and beneficiaries.

Table 2: The defining characteristics of implementation research applied in global health

\begin{tabular}{|l|l|}
\hline Context - specific & $\begin{array}{l}\text { Contextualisation of an intervention in implementation research, } \\
\text { hence the detail of context is made explicit, alongside level of } \\
\text { analysis and action e.g. community, district, national. Attention is } \\
\text { paid to the differences in need for, and benefit from interventions } \\
\text { depending on gender or other social strata. }\end{array}$ \\
\hline $\begin{array}{l}\text { Purpose - relevant and agenda } \\
\text { setting }\end{array}$ & $\begin{array}{l}\text { Identify and address challenges related to any implementation } \\
\text { decisions or processes at any level including: identifying and } \\
\text { addressing current health problems; agenda-setting; priority- } \\
\text { setting; commitment-building at all levels; }\end{array}$ \\
\hline Methods fit for purpose & $\begin{array}{l}\text { Research design responsive to an implementation problem or } \\
\text { question, typically a range of data sources and methods are used }\end{array}$ \\
\hline
\end{tabular}




\begin{tabular}{|c|c|}
\hline & $\begin{array}{l}\text { as appropriate for the implementation questions, decision context } \\
\text { and community or patient characteristics being sensitive to gender } \\
\text { and other social stratifiers. }\end{array}$ \\
\hline Demand driven & $\begin{array}{l}\text { Research questions are framed or based on needs identified by } \\
\text { implementers, intended beneficiaries, and/or policy-makers and } \\
\text { research consumers in the health system }\end{array}$ \\
\hline $\begin{array}{l}\text { Multi-stakeholder and } \\
\text { multidisciplinary }\end{array}$ & $\begin{array}{l}\text { Democratization of research: Implementers, policy makers and } \\
\text { researchers (and often also communities, including the most } \\
\text { marginalised) to co-produce the research, co-create solutions, } \\
\text { and use the results together drawing on multiple disciplines (e.g. } \\
\text { management, psychology, sociology, education, epidemiology, } \\
\text { anthropology, engineering, political science, and economics). } \\
\text { Importance of leadership or partnership of national scientists }\end{array}$ \\
\hline Real world & $\begin{array}{l}\text { Not usually under controlled trial conditions (but can be part of } \\
\text { pragmatic trials with process and context assessment running } \\
\text { alongside), and usually working within the reality of implementing } \\
\text { organizations, communities, and financing systems, and within the } \\
\text { context of health systems that are changing and adaptive. }\end{array}$ \\
\hline Real time & $\begin{array}{l}\text { Implementation research is designed to provide evidence or } \\
\text { solutions through short feedback loops that can be used for real } \\
\text { time improvements and/or course-correction in implementation } \\
\text { and/or periodic reflection, dynamic, non-linear, iterative, and } \\
\text { evolving process. }\end{array}$ \\
\hline $\begin{array}{l}\text { Focuses on processes as well as } \\
\text { outcomes/impact }\end{array}$ & $\begin{array}{l}\text { Implementation research is focused on processes and engage } \\
\text { implementers to and documents how interventions are } \\
\text { implemented and delivered to assess acceptability, fidelity, } \\
\text { adoption, scale up and impact. Tacit knowledge is used and } \\
\text { acknowledged. }\end{array}$ \\
\hline
\end{tabular}

\section{Sources: Authors. Informed by expert review process and adapted from Peters et a ${ }^{17}$; Cape Town statement, $2014^{5}$}

\section{Panel 4: Meetings on Implementation Research that informed the case studies}

The approach involved the identification of multiple case studies of implementation research projects in differing LMIC contexts, analysing these within a framework of core characteristics of implementation research adapted from the literature. ${ }^{5,17}$ The selection of case studies in this paper has been informed by a set of structured and consultative international meetings which aimed to bring together different stakeholders with an interest in implementation research in LMICs to identify problems and opportunities related to implementation research, build consensus in describing the field, showcase useful examples, and develop priorities for action. This series of meetings include: Developing and finalising the Guide "Implementation Research in Health: A Practical Guide" (Geneva, 2012) ${ }^{17}$; consultations on the priorities for statement on IRDS (Washington, April 2014 \& Accra, July 2014); launch of the "Statement on Advancing Implementation Research and Delivery Science" at the Health Systems Global Conference (Cape Town, October 2014); and two paper writing workshops (Washington, November, 2015 and Montreux April, 2016). The statement in Cape Town ${ }^{5}$ also involved a web statement that different stakeholders (e.g. health managers, donors, researchers) and their institutions signed up to, with actions to take forward the field. 
We have structured the case studies against this classification of impact in order to showcase a range of implementation research examples at different levels of the health system (Table 3). 
Table 3: Applying the defining characteristics of implementation research to the case studies

\begin{tabular}{|c|c|c|c|c|c|c|c|c|}
\hline CASE & $\begin{array}{l}\text { CONTEXT- } \\
\text { SPECIFIC }\end{array}$ & $\begin{array}{l}\text { PURPOSE - } \\
\text { RELEVANT } \\
\text { AND AGENDA } \\
\text { SETTING }\end{array}$ & $\begin{array}{l}\text { METHODS FIT } \\
\text { FOR PURPOSE }\end{array}$ & $\begin{array}{l}\text { DEMAND } \\
\text { DRIVEN }\end{array}$ & $\begin{array}{l}\text { MULTI- } \\
\text { STAKEHOLDER AND } \\
\text { MULTIDISCIPLINARY }\end{array}$ & $\begin{array}{l}\text { REAL } \\
\text { WORLD }\end{array}$ & REAL TIME & $\begin{array}{l}\text { FOCUSES ON } \\
\text { PROCESSES AS } \\
\text { WELL AS } \\
\text { OUTCOMES/IMPA } \\
\text { CT }\end{array}$ \\
\hline \multicolumn{9}{|c|}{ IMPLEMENTATION RESEARCH THAT HAS POSITIVE HEALTH IMPACT } \\
\hline $\begin{array}{l}\text { SMALL POX } \\
\text { ERADICATION }\end{array}$ & $\begin{array}{l}\text { Nigeria, } \\
\text { working } \\
\text { specifically } \\
\text { with } \\
\text { affected } \\
\text { villages } \\
\text { within the } \\
\text { context of a } \\
\text { nationwide } \\
\text { strategy }\end{array}$ & $\begin{array}{l}\text { Addressed } \\
\text { the challenge } \\
\text { of small pox } \\
\text { outbreak } \\
\text { when there } \\
\text { was not } \\
\text { enough } \\
\text { vaccine to } \\
\text { use the } \\
\text { standard } \\
\text { national } \\
\text { mass } \\
\text { vaccination } \\
\text { strategy }\end{array}$ & $\begin{array}{l}\text { "Field } \\
\text { research" } \\
\text { involving "ring- } \\
\text { fenced" } \\
\text { immunization } \\
\text { and active } \\
\text { surveillance in } \\
\text { communities } \\
\text { where new } \\
\text { cases } \\
\text { occurred. }\end{array}$ & $\begin{array}{l}\text { Health } \\
\text { providers } \\
\text { identified } \\
\text { the problem }\end{array}$ & $\begin{array}{l}\text { Co-creation with } \\
\text { implementers and } \\
\text { researchers tightly } \\
\text { linked, and } \\
\text { dependent on and } \\
\text { supported by } \\
\text { community } \\
\text { participation in } \\
\text { surveillance }\end{array}$ & $\begin{array}{l}\text { Working } \\
\text { with } \\
\text { affected } \\
\text { Nigerian } \\
\text { communitie } \\
\text { s and with } \\
\text { the health } \\
\text { system }\end{array}$ & $\begin{array}{l}\text { Implementati } \\
\text { on occurred } \\
\text { alongside } \\
\text { and in } \\
\text { response to } \\
\text { the small pox } \\
\text { outbreak }\end{array}$ & $\begin{array}{l}\text { Contributed and } \\
\text { built the } \\
\text { processes for an } \\
\text { effective } \\
\text { eradication } \\
\text { strategy despite } \\
\text { resource } \\
\text { constraints; } \\
\text { similar strategies } \\
\text { adopted later in } \\
\text { the Ebola } \\
\text { response }\end{array}$ \\
\hline $\begin{array}{l}\text { NEONATAL } \\
\text { MORTALITY DUE } \\
\text { TO BACTERIAL } \\
\text { INFECTION }\end{array}$ & $\begin{array}{l}\text { Urban and } \\
\text { peri-urban, } \\
\text { and rural } \\
\text { settings in } \\
\text { Bangladesh, } \\
\text { Pakistan, } \\
\text { DR Congo, } \\
\text { Kenya, } \\
\text { Nigeria }\end{array}$ & $\begin{array}{l}\text { Systematic } \\
\text { process from } \\
\text { validation } \\
\text { through } \\
\text { introduction } \\
\text { of new } \\
\text { approach to } \\
\text { increase } \\
\text { access and } \\
\text { ensure safety } \\
\text { of lifesaving } \\
\text { antibiotic } \\
\text { treatment for } \\
\text { sepsis }\end{array}$ & $\begin{array}{l}\text { Range of } \\
\text { methods } \\
\text { adjusted over } \\
\text { time including } \\
\text { clinical } \\
\text { assessments } \\
\text { of impact of } \\
\text { two days of } \\
\text { injectable } \\
\text { antibiotics and } \\
7 \text { days of oral } \\
\text { antibiotics and } \\
\text { quality } \\
\text { improvement }\end{array}$ & $\begin{array}{l}\text { The IR } \\
\text { process } \\
\text { responds to } \\
\text { need for } \\
\text { alternative } \\
\text { approaches } \\
\text { to address } \\
\text { bacterial } \\
\text { infection, } \\
\text { that are } \\
\text { acceptable } \\
\text { to } \\
\text { communities }\end{array}$ & $\begin{array}{l}\text { Implementers, policy } \\
\text { makers, and } \\
\text { researchers in } \\
\text { ongoing dialogue on } \\
\text { clinical research and } \\
\text { evolution to co- } \\
\text { creation of solutions } \\
\text { in later stage }\end{array}$ & $\begin{array}{l}\text { A locally } \\
\text { developed } \\
\text { service } \\
\text { package } \\
\text { was tested } \\
\text { using usual } \\
\text { manageme } \\
\text { nt } \\
\text { arrangeme } \\
\text { nt, followed } \\
\text { by further } \\
\text { adaptation } \\
\text { in real } \\
\text { world } \\
\text { conditions }\end{array}$ & $\begin{array}{l}\text { Initially no, } \\
\text { but later } \\
\text { stage effort } \\
\text { increasingly } \\
\text { so }\end{array}$ & $\begin{array}{l}\text { Assessment and } \\
\text { sharing of } \\
\text { learning across } \\
\text { contexts to inform } \\
\text { country level and } \\
\text { global uptake; } \\
\text { Bangladesh has } \\
\text { adopted WHO } \\
\text { guidelines and } \\
\text { ongoing iterative } \\
\text { process of } \\
\text { assessment to } \\
\text { inform scale up }\end{array}$ \\
\hline \multicolumn{9}{|c|}{ IMPLEMENTATION RESEARCH THAT INFORMS POLICY DESIGN AND IMPLEMENTATION } \\
\hline $\begin{array}{l}\text { GHANA- } \\
\text { COMMUNITY }\end{array}$ & $\begin{array}{l}\text { Ghana, } \\
\text { nationwide }\end{array}$ & $\begin{array}{l}\text { Identified the } \\
\text { importance of }\end{array}$ & $\begin{array}{l}\text { The original } \\
\text { research }\end{array}$ & $\begin{array}{l}\text { In response } \\
\text { to policy }\end{array}$ & $\begin{array}{l}\text { Policy makers, } \\
\text { program }\end{array}$ & $\begin{array}{l}\text { Working } \\
\text { within }\end{array}$ & $\begin{array}{l}\text { Ongoing } \\
\text { research to }\end{array}$ & $\begin{array}{l}\text { Demonstrates the } \\
\text { process and }\end{array}$ \\
\hline
\end{tabular}




\begin{tabular}{|c|c|c|c|c|c|c|c|c|}
\hline CASE & $\begin{array}{l}\text { CONTEXT- } \\
\text { SPECIFIC }\end{array}$ & $\begin{array}{l}\text { PURPOSE - } \\
\text { RELEVANT } \\
\text { AND AGENDA } \\
\text { SETTING }\end{array}$ & $\begin{array}{l}\text { METHODS FIT } \\
\text { FOR PURPOSE }\end{array}$ & $\begin{array}{l}\text { DEMAND } \\
\text { DRIVEN }\end{array}$ & $\begin{array}{l}\text { MULTI- } \\
\text { STAKEHOLDER AND } \\
\text { MULTIDISCIPLINARY }\end{array}$ & $\begin{array}{l}\text { REAL } \\
\text { WORLD }\end{array}$ & REAL TIME & $\begin{array}{l}\text { FOCUSES ON } \\
\text { PROCESSES AS } \\
\text { WELL AS } \\
\text { OUTCOMES/IMPA } \\
\text { CT }\end{array}$ \\
\hline $\begin{array}{l}\text { BASED HEALTH } \\
\text { SERVICES }\end{array}$ & $\begin{array}{l}\text { process to } \\
\text { promote } \\
\text { scaling up } \\
\text { approaches }\end{array}$ & $\begin{array}{l}\text { supporting, } \\
\text { sustaining } \\
\text { the scaling } \\
\text { up of } \\
\text { community } \\
\text { based health } \\
\text { services }\end{array}$ & $\begin{array}{l}\text { showed the } \\
\text { intervention } \\
\text { works and } \\
\text { how to go } \\
\text { about it. } \\
\text { However there } \\
\text { was no } \\
\text { research to } \\
\text { support how } \\
\text { to scale up in } \\
\text { context. }\end{array}$ & $\begin{array}{l}\text { maker } \\
\text { concern } \\
\text { over how to } \\
\text { effectively } \\
\text { implement } \\
\text { community } \\
\text { based } \\
\text { health } \\
\text { services and } \\
\text { address the } \\
\text { failures of } \\
\text { preceding } \\
\text { VHW } \\
\text { programs }\end{array}$ & $\begin{array}{l}\text { implementers and } \\
\text { politicians went } \\
\text { through an } \\
\text { interactive and } \\
\text { engaging process to } \\
\text { set the agenda and } \\
\text { follow the progress } \\
\text { of the research and } \\
\text { translate knowledge } \\
\text { into national policy } \\
\text { and program }\end{array}$ & $\begin{array}{l}\text { programme } \\
\text { realities } \\
\text { through an } \\
\text { ongoing } \\
\text { iterative } \\
\text { process }\end{array}$ & $\begin{array}{l}\text { inform } \\
\text { processes of } \\
\text { scale up in } \\
\text { real time }\end{array}$ & $\begin{array}{l}\text { impact of scaling } \\
\text { up throughout the } \\
\text { country through } \\
\text { experimentation, } \\
\text { multiple } \\
\text { validations, and } \\
\text { adaptation. }\end{array}$ \\
\hline $\begin{array}{l}\text { AFGHANISTAN- } \\
\text { BALNCED } \\
\text { SCORE CARD }\end{array}$ & $\begin{array}{l}\text { Afghanistan, } \\
\text { nation wide } \\
\text { approach with } \\
\text { pilots in } \\
\text { different } \\
\text { districts }\end{array}$ & $\begin{array}{l}\text { Responding } \\
\text { to the need to } \\
\text { provide and } \\
\text { assess the } \\
\text { provision of } \\
\text { basic } \\
\text { package of } \\
\text { health } \\
\text { services } \\
\text { across the } \\
\text { country }\end{array}$ & $\begin{array}{l}\text { Serial health } \\
\text { facility } \\
\text { surveys, } \\
\text { cluster } \\
\text { randomized } \\
\text { trial, and } \\
\text { process } \\
\text { evaluation }\end{array}$ & $\begin{array}{l}\text { Linked to } \\
\text { both } \\
\text { government } \\
\text { priorities } \\
\text { and to both } \\
\text { government } \\
\text { and NGO } \\
\text { intervention } \\
\text { s }\end{array}$ & $\begin{array}{l}\text { Involved } \\
\text { government, } \\
\text { NGOs and } \\
\text { researchers }\end{array}$ & $\begin{array}{l}\text { Working } \\
\text { within the } \\
\text { realities of } \\
\text { different } \\
\text { districts in this } \\
\text { fragile and } \\
\text { conflict } \\
\text { affected state }\end{array}$ & $\begin{array}{l}\text { Developing, } \\
\text { implementing } \\
\text { and } \\
\text { assessing } \\
\text { basic } \\
\text { package of } \\
\text { health } \\
\text { services in } \\
\text { real time }\end{array}$ & $\begin{array}{l}\text { Documented } \\
\text { process of } \\
\text { developing } \\
\text { balanced score } \\
\text { card; impact } \\
\text { including being } \\
\text { part of the } \\
\text { evidence base for } \\
\text { dropping user } \\
\text { fees }\end{array}$ \\
\hline $\begin{array}{l}\text { MULTI- } \\
\text { SECTORAL } \\
\text { NUTRITION } \\
\text { APPROACHES } \\
\text { TO REDUCE } \\
\text { STUNTING }\end{array}$ & $\begin{array}{l}\text { Working } \\
\text { within } \\
\text { national } \\
\text { processes } \\
\text { and } \\
\text { collaboratio } \\
\text { ns in } \\
\text { Ethiopia, } \\
\text { Uganda, } \\
\text { Burkina }\end{array}$ & $\begin{array}{l}\text { Addressed } \\
\text { the need for } \\
\text { joined up } \\
\text { approaches } \\
\text { between } \\
\text { actors and } \\
\text { sectors to } \\
\text { make impact } \\
\text { on nutrition } \\
\text { across } \\
\text { different }\end{array}$ & $\begin{array}{l}\text { Engaged, } \\
\text { embedded } \\
\text { action } \\
\text { research/ } \\
\text { developmental } \\
\text { evaluation of } \\
\text { national policy } \\
\text { implementatio } \\
\text { n. Method } \\
\text { deliberatively } \\
\text { chosen to }\end{array}$ & $\begin{array}{l}\text { Actively } \\
\text { responding } \\
\text { to the need } \\
\text { for more } \\
\text { joined up } \\
\text { approaches } \\
\text { identified in } \\
\text { county and } \\
\text { globally }\end{array}$ & $\begin{array}{l}\text { Researchers, policy } \\
\text { makers and } \\
\text { practitioners from } \\
\text { different sectors } \\
\text { interacting in formal } \\
\text { and informal venues } \\
\text { to address } \\
\text { immediate and } \\
\text { longer-term system } \\
\text { needs }\end{array}$ & $\begin{array}{l}\text { Led by } \\
\text { implemente } \\
\text { rs with } \\
\text { support } \\
\text { from } \\
\text { researcher } \\
\text { s from } \\
\text { project lead } \\
\text { team }\end{array}$ & $\begin{array}{l}\text { IR driving the } \\
\text { promotion of } \\
\text { multisectoral } \\
\text { approaches } \\
\text { for joined up } \\
\text { action on } \\
\text { malnutrition \& } \\
\text { stunting }\end{array}$ & $\begin{array}{l}\text { Addressed } \\
\text { numerous } \\
\text { bottlenecks in } \\
\text { real-time and } \\
\text { identified three } \\
\text { critical } \\
\text { investments that } \\
\text { appear necessary } \\
\text { in the long run, to } \\
\text { build and sustain } \\
\text { effective MSN }\end{array}$ \\
\hline
\end{tabular}




\begin{tabular}{|c|c|c|c|c|c|c|c|c|}
\hline CASE & $\begin{array}{l}\text { CONTEXT- } \\
\text { SPECIFIC }\end{array}$ & $\begin{array}{l}\text { PURPOSE - } \\
\text { RELEVANT } \\
\text { AND AGENDA } \\
\text { SETTING }\end{array}$ & $\begin{array}{l}\text { METHODS FIT } \\
\text { FOR PURPOSE }\end{array}$ & $\begin{array}{l}\text { DEMAND } \\
\text { DRIVEN }\end{array}$ & $\begin{array}{l}\text { MULTI- } \\
\text { STAKEHOLDER AND } \\
\text { MULTIDISCIPLINARY }\end{array}$ & $\begin{array}{l}\text { REAL } \\
\text { WORLD }\end{array}$ & REAL TIME & $\begin{array}{l}\text { FOCUSES ON } \\
\text { PROCESSES AS } \\
\text { WELL AS } \\
\text { OUTCOMES/IMPA } \\
\text { CT }\end{array}$ \\
\hline & $\begin{array}{l}\text { Faso and } \\
\text { Mali }\end{array}$ & $\begin{array}{l}\text { country } \\
\text { contexts }\end{array}$ & $\begin{array}{l}\text { support } \\
\text { commitment } \\
\text { building and } \\
\text { co-creation of } \\
\text { solutions }\end{array}$ & & & & & $\begin{array}{l}\text { systems to } \\
\text { reduce stunting }\end{array}$ \\
\hline $\begin{array}{l}\text { DISTRICT } \\
\text { HEALTH } \\
\text { SYSTEMS } \\
\text { UNDER } \\
\text { CONSTANT AND } \\
\text { CHANGING } \\
\text { CHALLENGE }\end{array}$ & $\begin{array}{l}\text { South } \\
\text { Africa, } \\
\text { Tanzania, } \\
\text { Ghana, } \\
\text { Uganda and } \\
\text { Nepal }\end{array}$ & $\begin{array}{l}\text { All the } \\
\text { projects and } \\
\text { processes } \\
\text { supported the } \\
\text { strengthening } \\
\text { and building } \\
\text { of quality and } \\
\text { more } \\
\text { responsive } \\
\text { health } \\
\text { systems at } \\
\text { the district } \\
\text { level }\end{array}$ & $\begin{array}{l}\text { Action } \\
\text { research and } \\
\text { processes of } \\
\text { co-learning } \\
\text { between } \\
\text { researchers } \\
\text { and } \\
\text { implementers } \\
\text { to support co- } \\
\text { creation of } \\
\text { solutions }\end{array}$ & $\begin{array}{l}\text { All IR } \\
\text { processes } \\
\text { responded } \\
\text { to the } \\
\text { expressed } \\
\text { need for } \\
\text { health } \\
\text { systems } \\
\text { strengthenin } \\
\text { g at the } \\
\text { district, } \\
\text { where } \\
\text { health } \\
\text { systems are } \\
\text { arguably } \\
\text { realized }\end{array}$ & $\begin{array}{l}\text { Partnerships } \\
\text { between district } \\
\text { health management } \\
\text { teams, managers, } \\
\text { health facility } \\
\text { management } \\
\text { committee and } \\
\text { researchers, in some } \\
\text { cases including } \\
\text { sectors beyond } \\
\text { health. Policy- } \\
\text { makers involved } \\
\text { throughout }\end{array}$ & $\begin{array}{l}\text { Working } \\
\text { within the } \\
\text { resource } \\
\text { constraints } \\
\text { at district } \\
\text { level }\end{array}$ & $\begin{array}{l}\text { In real time - } \\
\text { in Nepal the } \\
\text { IR approach } \\
\text { facilitated an } \\
\text { immediate } \\
\text { research } \\
\text { response } \\
\text { following the } \\
\text { earthquake, a } \\
\text { halt to } \\
\text { implementati } \\
\text { on of the } \\
\text { management } \\
\text { system and a } \\
\text { refocus on } \\
\text { how best to } \\
\text { support } \\
\text { health } \\
\text { workers } \\
\text { responding to } \\
\text { the crisis. }\end{array}$ & $\begin{array}{l}\text { Demonstrated } \\
\text { across different } \\
\text { contexts and } \\
\text { projects that } \\
\text { strengthening } \\
\text { approaches can } \\
\text { enable impact } \\
\text { and action even } \\
\text { in remote and } \\
\text { challenging } \\
\text { district contexts. } \\
\text { The partnerships } \\
\text { required for } \\
\text { change are } \\
\text { documented. }\end{array}$ \\
\hline $\begin{array}{l}\text { RESPECT FOR } \\
\text { MATERNITY } \\
\text { CARE }\end{array}$ & $\begin{array}{l}\text { Kenya, } \\
\text { Tanzania } \\
\text { and global } \\
\text { level } \\
\text { dialogue }\end{array}$ & $\begin{array}{l}\text { Responding } \\
\text { to a problem } \\
\text { that has too } \\
\text { often ignored } \\
\text { in the health } \\
\text { system in } \\
\text { LMIC and } \\
\text { industrialized } \\
\text { countries }\end{array}$ & $\begin{array}{l}\text { Problem } \\
\text { scoping } \\
\text { followed by } \\
\text { identification } \\
\text { of multi-level } \\
\text { intervention }\end{array}$ & $\begin{array}{l}\text { Responsive } \\
\text { to } \\
\text { unaddresse } \\
\text { d problem }\end{array}$ & $\begin{array}{l}\text { Dialogue and } \\
\text { evolving } \\
\text { partnerships to } \\
\text { address complex } \\
\text { multi-dimensional } \\
\text { problem }\end{array}$ & $\begin{array}{l}\text { Working in } \\
\text { program } \\
\text { realities } \\
\text { with co- } \\
\text { learning \& } \\
\text { implementa } \\
\text { tion of } \\
\text { policy } \\
\text { makers, }\end{array}$ & $\begin{array}{l}\text { Ongoing with } \\
\text { service } \\
\text { delivery }\end{array}$ & $\begin{array}{l}\text { Documentation } \\
\text { and development } \\
\text { of tools for } \\
\text { introduction and } \\
\text { scale up for } \\
\text { countries as well } \\
\text { as other settings }\end{array}$ \\
\hline
\end{tabular}




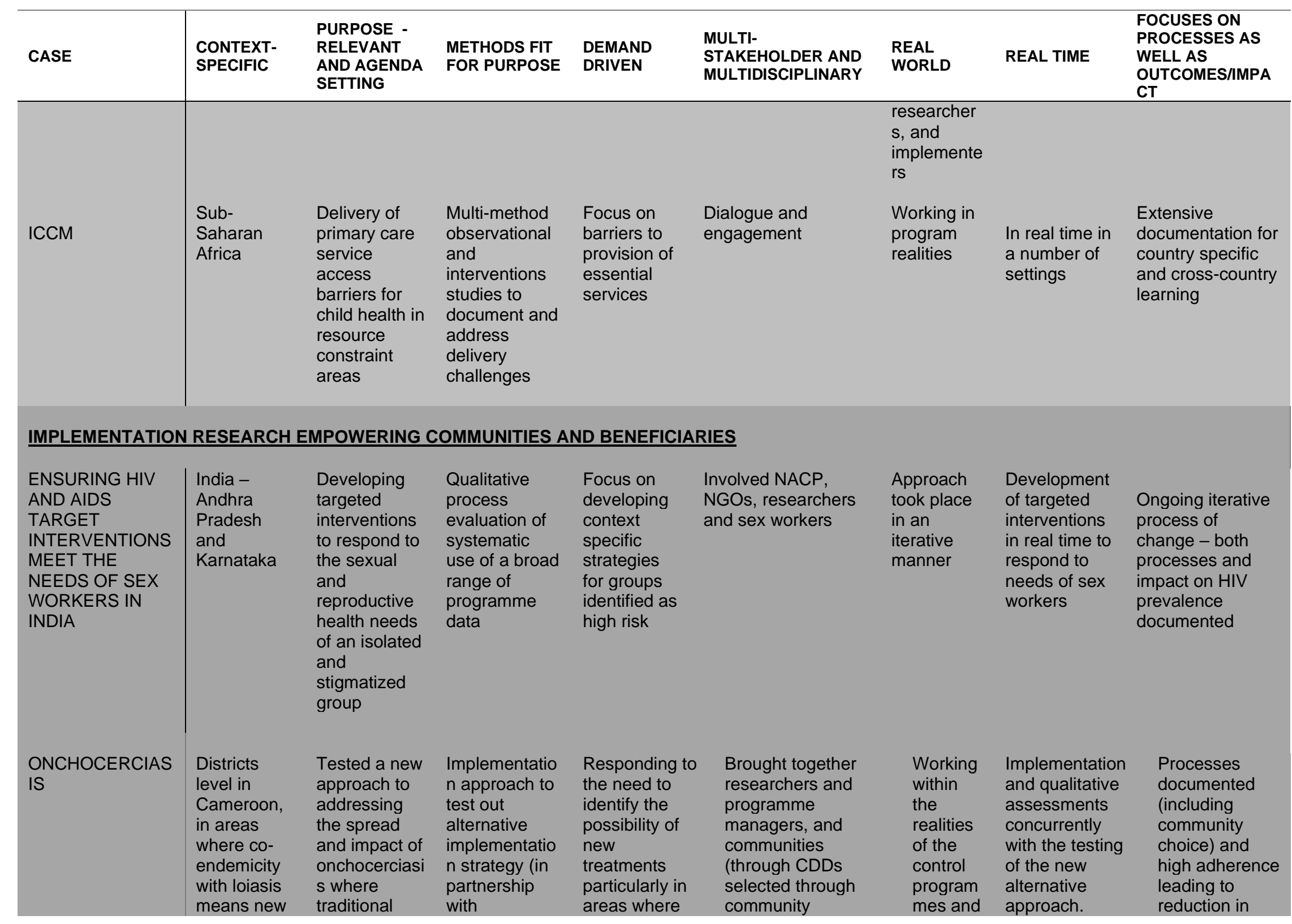




\begin{tabular}{|c|c|c|c|c|c|c|c|c|}
\hline CASE & $\begin{array}{l}\text { CONTEXT- } \\
\text { SPECIFIC }\end{array}$ & $\begin{array}{l}\text { PURPOSE - } \\
\text { RELEVANT } \\
\text { AND AGENDA } \\
\text { SETTING } \\
\end{array}$ & $\begin{array}{l}\text { METHODS FIT } \\
\text { FOR PURPOSE }\end{array}$ & $\begin{array}{l}\text { DEMAND } \\
\text { DRIVEN }\end{array}$ & $\begin{array}{l}\text { MULTI- } \\
\text { STAKEHOLDER AND } \\
\text { MULTIDISCIPLINARY }\end{array}$ & $\begin{array}{l}\text { REAL } \\
\text { WORLD }\end{array}$ & REAL TIME & $\begin{array}{l}\text { FOCUSES ON } \\
\text { PROCESSES AS } \\
\text { WELL AS } \\
\text { OUTCOMES/IMPA } \\
\text { CT } \\
\end{array}$ \\
\hline & $\begin{array}{l}\text { approaches } \\
\text { are required }\end{array}$ & $\begin{array}{l}\text { approaches } \\
\text { need } \\
\text { adapting (due } \\
\text { to co- } \\
\text { endemicity } \\
\text { with loaiasis } \\
\text { and severe } \\
\text { adverse } \\
\text { events). }\end{array}$ & $\begin{array}{l}\text { community } \\
\text { structures to } \\
\text { support } \\
\text { adherence } \\
\text { over } 10 \\
\text { weeks) with } \\
\text { embedded } \\
\text { qualitative } \\
\text { research \& } \\
\text { community } \\
\text { assessments }\end{array}$ & $\begin{array}{l}\text { loiasis highly } \\
\text { endemic }\end{array}$ & $\begin{array}{l}\text { processes ) and } \\
\text { deployed different } \\
\text { disciplines. } \\
\text { Developing trusting } \\
\text { relationships. }\end{array}$ & $\begin{array}{l}\text { in } \\
\text { partners } \\
\text { hip with } \\
\text { commun } \\
\text { ity } \\
\text { resource } \\
\text { s } \\
\text { (commu } \\
\text { nity } \\
\text { based } \\
\text { drug } \\
\text { distribut } \\
\text { ors) }\end{array}$ & & $\begin{array}{l}\text { prevalence and } \\
\text { infection rate, } \\
\text { enhanced well- } \\
\text { being and } \\
\text { policy change }\end{array}$ \\
\hline
\end{tabular}




\section{Implementation research that impacts people's health}

Smallpox eradication. The smallpox campaign remains the only successfully completed global health eradication campaign to date. One of the most dramatic and effective uses of implementation research involved testing a new implementation strategy for smallpox eradication using real-time data. The purposeful application of different research approaches was critical to the smallpox campaign. This included research on different ways to deliver vaccines, such as the bifurcated needle invented in 1965 that enabled quick and efficient immunization of large numbers of people. But when it became apparent that there was a critical shortage of vaccines to be able to pursue the long-standing strategy against smallpox - national mass vaccination - "field research" (as it was known in the Smallpox Programme) was needed to test a novel implementation strategy. The new approach involved a surveillance containment or "ring vaccination", whereby response teams rapidly moved into areas where there were newly identified cases and quickly vaccinated everyone in the affected villages to build rings of resistance around smallpox cases. Implementation research tracked the number of new smallpox cases over time, demonstrating how the new ring strategy led to an immediate decline in the transmission of cases in Nigeria over one high transmission season and then throughout the year. This led to the successful adoption of the ring strategy across West Africa and then around the world. ${ }^{20}$ More recently, the ring strategy was adapted in an innovative way to test the effectiveness of a new Ebola vaccine during the recent Ebola epidemic in Guinea. ${ }^{21}$

Neonatal Survival. A more recent case involved the testing of locally developed packages of services to improve newborn survival on a large scale in several low-income countries. This case offers a lesson in how implementation research done in "real world" conditions using locally available resources can change practices on a large scale and demonstrate the lives saved. Sepsis or severe bacterial infection is a leading cause of neonatal death. Severe bacterial infection has a rapid onset and is difficult to definitively diagnose. Until recently the WHO 
recommendation was limited to hospitalization and treatment with injectable antibiotics for 10-14 days. This is not feasible for many families in Africa and Asia. ${ }^{22,23}$ While hospitalization remains the WHO standard of care, a coordinated set of studies in Africa, Bangladesh and Pakistan established a new evidence base of implementation strategies for outpatient management, where necessary, which have been included in new WHO guidance. ${ }^{23,24}$ The simplest of these regimens involves two days of injectable antibiotics and 7 days of oral antibiotics with follow up. Rather than studying these new strategies in better funded settings or under conditions where research teams could control the quality of care, the studies were designed from the outset to address the realities of severely constrained resources, including limited qualified doctors and nurses and unreliable infrastructure, and were tested concurrently in five countries and across health system contexts. ${ }^{25,26}$ In Bangladesh, the government adopted the new WHO guidance as a result of their studies demonstrating how to achieve a $20 \%$ reduction in neonatal mortality. Following the principles of implementation research in global health, the government of Bangladesh is currently working with funding agencies, implementation groups and research partners to evaluate the broader effects of the adoption of the new guidelines, including evaluating the feasibility and safety of the new WHO guidelines in three different regions with different health systems, contexts and technical support. Reviews every three months will allow the refinement of the implementation process and planning for the national scale up. 


\section{Implementation research that informs policy}

Ghana: The Community Health and Planning Services (CHPS) is the lowest level at which public health services are delivered in Ghana. CHPS started as a family planning research project and then transformed into an initiative aimed at locating primary care services in communities, and involving them in the decision-making process. The CHPS experience brings to the fore the practicality of scaling up a successful pilot throughout the country, and what it takes to put evidence into action through research, experimentation, multiple validations, and adaptation.

Between 1994 and 2000, country stakeholders went through an interactive and engaging process to pilot, experiment, replicate and scale up a programme that mobilized local volunteers, resources and cultural institutions to support community based primary care ${ }^{27}$ The original CHPS model was piloted through deploying nurses to the community and engaging local leaders, resulting in reductions in child mortality by half, maternal mortality by $40 \%$ and fertility by nearly a birth in only five years, compared to areas relying on existing services alone. ${ }^{28}$ The key implementation research lessons to inform scale up were: the need to place nurses in home districts but not home villages; adapt to each district context; mobilize local resources; develop a shared project vision; conduct "exchanges" where staff can observe the model working in another setting; pilot the approach locally and expand based on lessons learned. Since 2000, the country has continued to gradually scale up the implementation of CHPS with both successes and challenges. A recent review by Krumholz et al $(2015)^{29}$ shows that the original scope of CHPS has been expanded which has increased access to health care; although some implementers are concerned that the original emphasis on community involvement does not have the same prominence as in the original study.

Afghanistan. The case of the development and use of a national Balanced Scorecard (BSC) on basic services in Afghanistan demonstrates how implementation research can be used to 
immediately influence policy, as well as the limitations and potential consequences of the close links of research and policy. The BSC in Afghanistan is part of a monitoring system set up through multi-stakeholder engagement to regularly assess the delivery of a basic package of health services across the country. The BSC was used as a tool for regular re-planning of activities, reallocation of resources, and problem-solving ${ }^{30}$ and also provided a platform to test government and NGO policy innovations, such as contracting and health financing innovations. ${ }^{31} \mathrm{~A}$ clusterrandomized trial using the BSC was conducted to test different user fee options, and within days of the study being completed, the results were quoted by the Ministry of Public Health (MOPH) as a basis for dropping user fees at primary care facilities due to their negative effects on access, while failing to improve quality or raise significant funding..$^{32}$ This was a policy the government had wanted to change and the research provided them with confidence to do so. More recently, when the same data collection system and revised scorecards were used to evaluate a pay-forperformance scheme that was shown to be ineffective, ${ }^{33}$ the MOPH expanded the program anyway with World Bank support, and has not paid the evaluators for the work. The experience demonstrates that close collaboration between policy-makers and researchers can result in research that directly leads to policy change, particularly when the results are consistent with government ambitions. But there are also risks to researchers when they work closely with government and the results do not support government expectations about their policies.

Nutrition Systems. Implementation research has been used effectively to build and sustain multisectoral nutrition systems (MSN) across Ethiopia, Uganda, Burkina Faso and Mali by identifying critical investments required in these systems. Malnutrition is a major contributor to the global burden of disease in low-income countries, with more than 2 billion people affected by micronutrient malnutrition and 161 million children suffering from chronic undernutrition. ${ }^{29}$ Establishing mutual understanding of the evidence of highly efficacious and cost-effective interventions by policy makers, researchers, and program managers ${ }^{34}$ have been the foundation 
for an increase in nutrition on global and national agendas. ${ }^{35-39}$ These communities also coalesced in the creation of Scaling Up Nutrition (SUN) promoting a multisectoral approach involving delivery of direct interventions and policy reforms in key sectors (e.g., health, agriculture and education), which aligns inputs from government, donors, NGOs and others, consistent with the evidence synthesized in a recent Lancet series. ${ }^{40}$ However, a recent evaluation of SUN reported that implementation at country level faces many challenges, including an "implementation disconnect". ${ }^{41}$ Actors and institutions at national and sub-national levels function as a complex adaptive system, but their implementation logic is based on bureaucratic-rational assumptions which ignores this complexity. Consequently, the various actors still have divergent mandates, incentives and accountabilities, the nascent, formal coordination structures lack the authority and capacity to coordinate, and the globally-prescribed monitoring and evaluation systems lack the contextually-relevant, nuanced and timely information needed during the system-building phase as implementation challenges are surfacing.

Recognizing this disconnect, an implementation research effort was undertaken in four SUN countries to provide real-time and customized information to country stakeholders to better understand implementation challenges based on key principle of strengthening strategic capacity, learning and adapting management, and sharing documented learning. The research identified three critical investments necessary to build and sustain effective MSN systems: 1) strengthening human resources in the MSN coordinating unit; (2) creating an implementation team to cascade learning and implementation throughout the country; and 3) ensuring that accurate information on critical bottlenecks is conveyed and acted upon swiftly by high level decision makers across the sectors. $^{42}$

\section{Implementation research to improve health management and service delivery}


District Health Systems Strengthening. A growing body of implementation research demonstrates the use of participatory research processes to support learning and district health systems strengthening. In the cases described below, the participatory action learning strategies have been assessed using a range of qualitative, participatory and quantitative methods, and have shown promising results, identifying the likely pathways of effect.

The PERFORM (Improving Health Workforce Performance) project has involved partnerships between researchers and District Health Management Teams (DHMTs) in decentralised contexts (Ghana, Tanzania and Uganda). Working in three districts in each country, a management strengthening intervention was implemented to identify workforce performance challenges and feasible "bundles of interventions" to address them. ${ }^{43}$ The project uses a systems approach where people involved in the health system use data to identify and address workforce problems, within the context of other health systems components that are also constraining the DHMTs. Examples of bundles of interventions include linking human resources strategies (e.g. attendance monitoring and appraisal) with strategies addressing wider health systems problems, such as by building competence and ensuring medical supplies are available. ${ }^{43}$ This management strengthening intervention is being scaled-up across these three African countries, with implementation research guiding this process. The Expandnet approach to scale-up ${ }^{44,45}$ is being used, which focuses on key principles: systems thinking - the interrelationships between the different stakeholders and the wider environment; sustainability - institutionalising the intervention into policies, guidelines and budgets; enhancing scalability through ongoing monitoring so that implementers are able to adapt the intervention and learn and improve scalability; and respect for human rights, equity and gender.

In the Ghana PERFORM sites, positive changes in service delivery and workforce performance indicators at district level include improvements in vaccination and drop-out rates and 
improvements in quality of HIV clinic services. Research was used to build management capacity in problem analysis and inform the design of integrated strategies for improving workforce performance and health systems. This resulted in strengthened supportive supervision, more regular feedback meetings, and improved documentation at the district and sub-district levels. ${ }^{47}$ There has also been an increase in initiative and risk-taking culture, teamwork and collaboration and empowerment. ${ }^{43}$

In Nepal an implementation research project used similar participatory processes as PERFORM to enhance health worker performance in three different districts and assessed the processes, effectiveness and feasibility to scale up. ${ }^{46}$ The key components of the intervention included orientating health workers and health facility operation and management committee to the performance management package, setting benchmarks for key service delivery indicators at facility level, group monitoring and assessment for staff, individual appraisal, supportive supervision and feedback, development of outcome focused job aids for health workers, and community assessment. The findings showed improved functionality of health service delivery with increased motivation level of health workers, which contributed to a reduction of health workers' absenteeism in a number of health facilities. Group monitoring and supportive supervision was considered one of the components that helped improve health workers' performance. This was linked to improvements in the quality of health services and has potentially contributed to improved health outcomes especially in maternal and child health. ${ }^{48}$

The District Innovation and Action Learning for Health Systems Development (DIAHLS) project in Mitchell Plain, South Africa, aims to strengthen leadership and governance within the district health system to support primary health care improvement and strengthen policy implementation. The approach has involved intervening in the routine processes of decision-making - the governance 'glue' of health systems. ${ }^{49}$ Here, the learning is negotiated \& constructed among 
practitioners and researchers ${ }^{50}$ to co-produce knowledge about how complex systems function and can be strengthened, and to support further action. The DIAHLS approach has included cycles of action learning working with providers at different levels and including relationship building, mentoring and coaching, reflection and writing, and implemented at both individual and team levels.

In Mitchell Plain Sub-district there have been impressive gains. For example, antenatal clients booked before 20 weeks gestational age improved from 114 clients booked in 2011 to 1452 clients in 2014. The HIV positivity rates in infants have been significantly reduced (PMTCT positivity rate declined from $1.8 \%$ ( 28 clients positive in cohort of 1570 PMTCT clients) in 2011 to $0.6 \%$ (9 clients positive in a cohort of 1564 PMTCT clients). ${ }^{51}$ Local system actors agree that the gains in managerial confidence, new managerial styles, positive attitudes and greater pro-activeness in identifying and tackling service challenges, at both facility and mid-level managerial levels, together with improved relationships across system levels and structures, has sustained and enhanced performance. ${ }^{49,52}$ There have also been spin offs - taking new ways of managing into new arenas, leading, for example, to innovative work addressing gender issues in a range of sectors that won local awards.

The learning from these different projects show that implementation research used for district strengthening can inform action and produce better results even in remote and challenging district contexts, with no additional financial resources. The impact on improved performance in delivering services is fostered where there is continuity and commitment of leadership, where there is a systems approach that identifies and addresses unintended consequences, engages key stakeholders and functions across the health system to catalyse wider change. Ultimately building trusting partnerships between researchers, health workers, managers and policy makers that facilitate the co-production of knowledge and action is critical. Trusting relationships with key 
stakeholders (including the Ministry of Health) in Nepal, ensured collaborative dialogue when the 2014 earthquake caused significant damage to one of the implementation research districts (Rasuwa). It was agreed that the originally planned management interventions could no longer be implemented in Rasuwa, but that the team should undertake quick qualitative assessments to describe changes in service delivery and working environments after the earthquake and develop recommendations for policy makers to reinforce coping strategies and supportive systems. The findings highlighted the resilience of health workers in providing services, the need for additional psycho-social support, compassionate leave and recognition..$^{53}$

Respectful Maternity Care. Disrespect, abuse, and neglect of women is a barrier to facilitybased birth as well as a violation of the human rights of pregnant and post-partum women. ${ }^{54}$ In Kenya and Tanzania, research studies have documented the prevalence of and factors associated with abuse. ${ }^{55}$ Research in Kenya involved a multi-level intervention initiated by a partnership of researchers, Ministry of Health officials, and other implementation agencies with multiple components, including draft legislation and guidelines and training for facility-based supportive counselling for health providers. ${ }^{56}$ Through close work with stakeholders, packages of interventions were developed and tested to reduce abuse. The study documented a reduction in overall disrespect and abuse from $20 \%$ to $13 \%$, despite the introduction of a national policy of free maternity care (presumably leading to higher utilisation) and nurses' strikes. ${ }^{57}$ Based upon these results, the government of Kenya is beginning a national scale up the strategy. Stimulated by the early findings of this and a companion study in Tanzania, WHO commissioned a review and released a policy statement ${ }^{24}$ and has embarked on a multi-country study to measure global prevalence. Concurrent to these efforts as well as these initial implementation research studies the White Ribbon Alliance has engaged in policy dialogue at country and global level, bringing this topic into the global and country level dialogues as well as stimulating further research efforts. 
Integrated Community Case Management. From 2008 - 2013 in the African region there has been strong investment across 36 countries to assess the impact of Integrated Community Case Management (iCCM), a delivery system using community health workers (CHWs) to deliver treatment for pneumonia, malaria and diarrhea to children closer to communities. The findings of these studies, led by a variety or implementers were mixed, often showing no mortality impact. ${ }^{58}$ Implementation research grounded in local contexts was needed to better understand different practices and outcomes in different contexts, and provide overall learning on how to best to adapt the implementation iCCM. Following in-depth consultation, recommendations were developed to focus research on a range of implementation issues ${ }^{59,60}$ including those highlighted in Table 4. 
Table 4: Examples of Implementation Research in iCCM against pre-defined priority areas from 2008-2016.

\begin{tabular}{|c|c|c|c|c|c|}
\hline & $\begin{array}{l}\text { Training and } \\
\text { Supervision }\end{array}$ & Supplies & Quality of Services & Deployment & Utilization \\
\hline $\begin{array}{l}\text { Cross-cutting } \\
\text { findings }\end{array}$ & $\begin{array}{l}\text { Training and } \\
\text { supervision } \\
\text { schedule, length } \\
\text { and approaches } \\
\text { varied, there is } \\
\text { some evidence } \\
\text { that consistent } \\
\text { on site } \\
\text { supervision } \\
\text { improves quality } \\
\text { of CHW } \\
\text { performance. }\end{array}$ & $\begin{array}{l}\text { Well supported, } \\
\text { often parallel, } \\
\text { systems ensure } \\
\text { limited stockouts } \\
\text { but when this is not } \\
\text { the case stockouts } \\
\text { are common }\end{array}$ & $\begin{array}{l}\text { CHWs and drug shop } \\
\text { attendees are capable } \\
\text { of providing high quality } \\
\text { diagnosis, treatment } \\
\text { and referrals but only } \\
\text { when well supported } \\
\text { (i.e. trained, supervised } \\
\text { and provided supplies } \\
\text { and job aids). }\end{array}$ & $\begin{array}{l}\text { CHWs may not be } \\
\text { being deployed } \\
\text { where most } \\
\text { needed (e.g. close } \\
\text { to public health } \\
\text { facilities or private } \\
\text { providers) }\end{array}$ & $\begin{array}{l}\text { Generally these } \\
\text { services have been } \\
\text { underutilized and } \\
\text { there may be } \\
\text { preference for } \\
\text { traditional, private or } \\
\text { health facilities over } \\
\text { iCCM but social } \\
\text { mobilization can } \\
\text { increase demand }\end{array}$ \\
\hline $\begin{array}{l}\text { Example of } \\
\text { context } \\
\text { specific } \\
\text { findings }\end{array}$ & $\begin{array}{l}\text { Supportive } \\
\text { supervision } \\
\text { (clinical } \\
\text { mentoring) visits } \\
\text { were effective in } \\
\text { improving the } \\
\text { consistency of } \\
\text { iCCM skills in } \\
\text { Health } \\
\text { Extension } \\
\text { workers in } \\
\text { Ethiopia. }\end{array}$ & $\begin{array}{l}\text { A mobile health } \\
\text { (mHealth) } \\
\text { technology - } \\
\text { cStock, for } \\
\text { reporting } \\
\text { on community stock } \\
\text { data in Malawi was } \\
\text { feasible and } \\
\text { acceptable and } \\
\text { resulted in lower } \\
\text { stockouts }\end{array}$ & $\begin{array}{l}\text { In Zambia, CHWs } \\
\text { providing iCCM } \\
\text { appropriately classified } \\
\text { malaria and/or } \\
\text { pneumonia } 94-100 \% \text { of } \\
\text { the time and provided } \\
\text { correct treatment in } 94- \\
100 \% \text { of episodes seen. }\end{array}$ & $\begin{array}{l}\text { In Sudan mapping } \\
\text { using GPS } \\
\text { showed that over } \\
\text { three-quarters of } \\
\text { CHWs were } \\
\text { deployed within a } \\
\text { five kilometer } \\
\text { radius of a health } \\
\text { facility } \\
\text { or another CHW, } \\
\text { contrary to } \\
\text { program planning } \\
\text { and design. }\end{array}$ & $\begin{array}{l}\text { In Niger and } \\
\text { Mozambique } \\
\text { demand increased } \\
\text { for iCCM services, } \\
\text { following the } \\
\text { implementation of } \\
\text { comprehensive } \\
\text { social mobilization } \\
\text { efforts. }\end{array}$ \\
\hline Implications & $\begin{array}{l}\text { Additional } \\
\text { research is } \\
\text { needed on the } \\
\text { optimal training } \\
\text { and supervision } \\
\text { approaches and } \\
\text { better } \\
\text { integration into }\end{array}$ & $\begin{array}{l}\text { Improve logistics of } \\
\text { supply chain for } \\
\text { overall health } \\
\text { system including } \\
\text { community } \\
\text { distribution }\end{array}$ & $\begin{array}{l}\text { Most well supported } \\
\text { programs were } \\
\text { implemented by NGOs, } \\
\text { sustaining support by } \\
\text { MOHs in struggling } \\
\text { health care systems is } \\
\text { unlikely unless it is } \\
\text { correlated with overall }\end{array}$ & $\begin{array}{l}\text { Increased } \\
\text { research with } \\
\text { geospatial } \\
\text { analysis of } \mathrm{CHWs} \\
\text { and health } \\
\text { facilities is needed }\end{array}$ & $\begin{array}{l}\text { Increase research } \\
\text { on understanding } \\
\text { uptake of health } \\
\text { care services and } \\
\text { increase social } \\
\text { mobilization and } \\
\text { demand generation }\end{array}$ \\
\hline
\end{tabular}




\begin{tabular}{|l|l|l|l|l|l|}
\hline & $\begin{array}{l}\text { Training and } \\
\text { Supervision }\end{array}$ & Supplies & Quality of Services & Deployment & Utilization \\
\hline $\begin{array}{l}\text { existing health } \\
\text { supervision and } \\
\text { training systems }\end{array}$ & & $\begin{array}{l}\text { improvements in the } \\
\text { health care system. }\end{array}$ & $\begin{array}{l}\text { and test their } \\
\text { impact. }\end{array}$ \\
\hline References & $49,50,61$ & $52,54,57-60,62-64$ & $49,54,56-60,62,63,65$ & $49,66,67$ & $68-71$ \\
\hline
\end{tabular}

* This is based on a review of the gray literature, reports from implementers on training and supervision. 
During this time period there have been large increases in supportive policies for iCCM and increased implementation in the Africa region. ${ }^{60}$ Delineating the specific impact of these implementation research studies on ICCM implementation in Africa is difficult, as iCCM policy development and implementation is influenced by the prevailing conditions of the health system in each country, their history of primary health care, the role of community health workers, and available funding and local champions and leaders. ${ }^{62,65}$ However, there is evidence from studies in three countries that policymakers greatly valued local implementation research and international research evidence was used to identify locally relevant policy options ${ }^{64}$ In addition, WHO and UNICEF functioned as knowledge brokers, bringing these implementation research findings from other countries through academic publications, statements, guidance documents, and meetings to the attention of local policymakers. ${ }^{63}$

\section{Implementation research to empower communities and beneficiaries}

People at risk for HIV and discrimination. The government of India developed the National AIDS Control Program (NACP), which involves the implementation of targeted interventions (TIs) to reduce HIV for key populations, including female sex workers (FSW). A qualitative process evaluation was undertaken in two states: Andhra Pradesh and Karnataka, to assess the ways in which Tls are appropriately adapted to FSWs needs and the changing contextual and programmatic factors. ${ }^{72}$ Establishing outreach activities for FSWs, many of whom were illiterate, was challenging as they are stigmatized, face extreme discrimination - including a history of violence at the hands of police and family members - and were not organized into support groups or associations. The outreach strategy required several refinements, including the hiring of peer educators of different ages, the creation of the drop-in centers, the introduction of pictorial materials, and the design and re-design of interventions acceptable to them. Similarly, the condom promotion and distribution strategy and clinical service delivery models evolved. Several 
models were implemented, adapted, and ultimately differentiated according to the needs of the clients. The most important component of the Tls was the gradual inclusion and integration of FSWs in the provision of services that were more responsive to their needs. The TIs started with needs assessments to a better understand the community of FSWs, revealing how addressing threats of violence and harassment are more important than HIV prevention. The regular involvement of the peer educators facilitated community-led interventions, eliciting interest in forming community-based organizations and generating greater community participation. This contributed to a social movement recognizing the rights of sex workers and their social entitlements.

The Tls benefited from a broad variety of implementation research, using multiple data sources inform implementation changes. The program used three major sources of data: periodic surveys and assessments; annual sentinel surveillance; and routine program data. The results were regularly triangulated to ensure their validity before decision-making and strategy refinement. A key lesson, however, is for managers to recognize that data will always have limitations, and they and that they needed to make "decisions based on the best available data rather than wait for the next sample or a more refined analysis". ${ }^{66}$ Using a quasi-experimental design that varied the level of intervention intensity, statistically significant declines in HIV prevalence among young pregnant women was observed between 2007 and 2011 in the districts with the highest intensity of targeted interventions without similar changes in lower intensity districts, suggesting they played a role in bringing about the decline. ${ }^{67}$

Community directed treatment for onchocerciasis. Community directed treatment with Ivermectin (CDTI) is a core activity in the control of onchocerciasis in Africa. The strategy relies on active community participation in the process of ivermectin delivery: the community decides how, when and by whom the ivermectin should be delivered. ${ }^{73,74}$ Several studies have 
demonstrated that Ivermectin alone cannot eliminate onchocerciasis, as it is active only on microfilariae, and its use is contraindicated in areas where Loa loa is highly endemic because individuals with high microfilarial loads of $L$. loa are at risk of serious adverse events. ${ }^{68,75,76}$ Recently, antibiotics targeting endosymbiotic bacteria (Wolbachia) of Onchocerca volvulus have been demonstrated to be a promising alternative tool for onchocerciasis control and elimination, particularly in areas of co-endemicity with loiasis, and has the added benefit of also killing adult worms. ${ }^{69,77}$ The implementation research process aimed to test the feasibility of a long course of antibiotic treatment ( 6 weeks). In the intervention arm of the clinical trial a rigorous process of community engagement was undertaken. First the team met with the community leaders to explain the process. Communities were then supported to select their own representatives who serve as community drug distributors (CDD). The CDDs were trained through an ongoing practical adult learning approach on the importance of adherence through the process of directly observed treatment. They were also supported in record keeping and strategies to ensure consistent supply of drugs through a process of health systems strengthening.

In a CDTI study in Cameroon, the intervention arm demonstrated very strong adherence rates (98\%), showing that it is feasible and acceptable to deliver a complex intervention over a sustained period at the community level. Health impact assessments were conducted four years later that demonstrated a $10 \%$ reduction in prevalence of the disease and a significant reduction in the number of parasites in people's skin, while qualitative assessments at community level revealed a strong sense of enhanced wellbeing. The awareness of onchocerciasis and its socioeconomic impacts on the population was a motivating factor for community adherence to treatment. As a result of the research, there has been policy changes in the programmes that have been adopted across Africa. Doxycycline is now used as an alternative to ivermectin in the control of onchocerciasis in areas highly endemic for L. loa. 


\section{Limitations of implementation research - a matter of balance}

As with any research endeavor, there are questions about the quality of research that are applicable to the methods chosen, which are every bit as relevant to those used in implementation research. But the trade-offs between the pursuit of rigorous methodology and the timeliness and utility of the research is a major consideration in implementation research. As a simple example, policy-makers often do not require a level of confidence of $p<0.05$ to make a decision, and may balk at expanding a sample size or the duration of a study simply to be able to do so. Another trade-off affecting implementation research is whether to identify and conduct research through processes embedded in a health organization being studied as engaged partners and actors in the policy and program process actors, or to work externally, where it is more possible to speak "truth to power" and provide a more objective view.

Another issue is that implementation research is often focused on answering a particular problem in a particular setting, limiting the generalizability or ability to learn in places other than where the study was conducted. Being explicit about the application of theory ${ }^{78}$ and using recently developed StaRI reporting guidelines on implementation research should help to improve this. ${ }^{18}$

Another common tension is between the need to study and maintain the fidelity (implementation according to its design) of a particular intervention compared to the need to be able to adapt the intervention and learn lessons in the course of implementation. Adaptations to the intervention often happen as it is being scaled up or as conditions change. Implementation research can provide valuable information to guide these adaptations so that they "fit" the different contexts and needs, demonstrating the importance of implementation research from the outset of the scale up of complex interventions. There is increasing recognition of the need to not only test the effectiveness of standardized interventions, but to use implementation research to support the evolution of interventions to fit the organizational and ecological contexts within which they are 
used. This approach recognizes that such adaptation can improve the outcomes of an intervention, rather than lead to an inevitable 'voltage drop' in effectiveness. ${ }^{79}$ Both approaches can be appropriate, but it is important that key stakeholders (e.g. researchers, authorizing and implementing agencies) are in agreement at the outset, or at least on how long they want to pursue a particular approach. One way of dealing with this in pragmatic trials is to have a design phase where the feasibility of different implementation arrangements or components are tested and agreed, and then fixed for the duration of the trial. ${ }^{80}$

Other tensions arise when balancing stakeholder interests and incentives within implementation research. Researchers need to spend time getting to know policy and practice organizations, as well as give up some level of control over their research. This requires skills and time that they may not have, in part due to the challenges of costing such time and meeting deadlines in conventional research funding proposals. Ceding control in this way requires a greater tolerance for uncertainty, but the payoff is frequently better engagement, a more immediate impact of the research and sustained engagement. However, if universities do not value research impact in their recognition and promotion criteria, this may be a risky endeavor, especially for junior academics. For implementing agencies and policy-makers, implementation research provides opportunities to improve their programs and services, but may also shine a light on their work, with real consequences if performance is poor. Despite these organizational tensions, improvements in accountability are likely to benefit patients and populations served by health systems. 


\section{Conclusion}

The case studies demonstrate the wide range of implementation research processes in terms of scale, topic, methods and range of impacts in global health. The impacts from implementation research do not always fit neatly into the categories we have used to describe them. The same research can affect health outcomes while also informing policy, improve health management and service delivery, and/or empower communities and beneficiaries. Many of the case studies illustrate how implementation research can be used to improve health service delivery within specific contexts, and discuss the processes that can inform scale up and efforts in other settings. Some of the case studies focus on vertical or disease specific interventions (e.g. smallpox, HIV, or onchocerciasis), and others on broader health systems strengthening (e.g. Afghanistan balanced scorecard and the district level cases). In the case of disease specific interventions, it is the implementation focus that brings in the need to acknowledge and address the broader health systems factors that can either enable or inhibit effective action, and raises other areas for critical consideration, such as community ownership and adaptation to community needs.

Context is critical to the implementation research endeavour, and the case studies make context explicit. Many of the case studies include implementation research processes across different county contexts and programmatic objectives. There are strategic opportunities to learn lessons across diverse contexts. The case study examples of national nutrition systems, iCCM, and strengthening health systems at district level illustrate a cumulative and growing body of knowledge about developing the health system's organisational capacity across multiple contexts and issues. Implementation research allows one to document processes to ensure that the depth and detail of what has been done is made explicit, so that adaptation to other contexts can be considered. Earlier work in this area has emphasized the importance of context and local and ongoing adaption. For example, a systematic review of 150 strategies to strengthen health services in LMICs highlighted significantly higher implementation outcomes when there was 
flexibility and modification through stakeholder feedback, constraints reduction plans, initial and continuous adaptation of the strategy to the local context, broad-based support of stakeholders, and coordination and community organization. ${ }^{70}$

Implementation research is about the "how to" of implementation - testing feasibility, adoption, and acceptance; and addressing quality, equity, efficiency, scale, sustainability and ensuring coverage to all, even the marginalised, with the ultimate goal of strengthening health systems to improve health outcomes. These endeavours involve a range of research methods, shaped according to the questions addressed and further iterative processes linking research, reflection and action. These processes play important roles in helping policy change to be realised, sustained, and have an impact.

The case studies also demonstrate how implementation research involves partnerships across the research and implementation cycles with co-production and concurrent use of knowledge. Dissemination alone is not sufficient to support real change. The core characteristics of implementation research, as shown in Table 2, include the nurturing of trusting partnerships to conduct real world, real-time research that addresses relevant implementation challenges. The case studies illustrate the importance of context and how health systems operate as complex adaptive systems ${ }^{71}$ and are constantly changing and shaped by the activities of a diverse set of actors who have different types of incentives to engage or not in implementation research. They illustrate approaches to complex issues in health systems strengthening, and how different stakeholders can learn from the work. Local leadership to support ownership, flexibility and responsiveness of research to the realities and challenges posed by changing, complex and adaptive health systems is important. Fragility and disaster bring into sharp focus the importance of trusting relationships and approaches that are both embedded and iterative in order to address the needs and realities of changing contexts. 
The implementation research and delivery science statement released at the Cape Town Global Symposium on Health Systems Research is a call to action to the Global Health Community (including academia, implementers, national and global health institutions and donors) to take up the challenge of strengthening implementation through productive partnerships between policy makers, implementers and researchers. ${ }^{5}$ Advancing implementation research will require overcoming some challenges including the misalignment of incentives in some academic institutions which discourages young academics from creating a career in this area and sharing experiences through networks and publications. The growing effort to produce guidelines for publishing implementation research reveals the limitation of current approaches and recognizes the importance of reporting studies in sufficient detail to permit replication or adaptation. ${ }^{67}$ This highlights the need for further dialogue between journals and authors on how to report the implementation process and learning from implementation research and the broader field of Health Policy and Systems research. Implementation research, as outlined in this paper, presents an opportunity to bridge the knowing-doing gap for the ultimate shared health impact that we researchers, policy-makers, program implementers, and communities seek to achieve. 


\section{Acknowledgments:}

With thanks for review and input: Mark Taylor, Irene Agyepong, Lucy Gilson, Daniela Rodriguez, Laura Reichenbach and Supriya Madhavan. Big thanks to Susie Crossman and Faye Moody for support with references. 


\section{REFERENCES}

1. Jamison DT, H. Gelband, S. Horton, P. Jha, R. Laxminarayan, C.N. Mock, and R. Nugent. Disease Control Priorities: Improving Health and Reducing Poverty. Disease Control Priorities. Third ed. Washington DC: World Bank; 2018.

2. Zuccala A. Modeling the invisible college. Journal of the American Society for Information Science and Technology 2006; 57: 152-68.

3. Eccles MP, Mittman B. S., . Welcome to Implementation Science. Implement Sci 2006; 1(1).

4. Peters DH, Adam T, Alonge O, Agyepong IA, Tran N. Implementation research: what it is and how to do it. BMJ 2013; 347: f6753.

5. Third Global Health Systems Research Symposium. Statement on Advancing Implementation Research and Delivery Science 2014.

6. L. Fixsen D, Naoom S, Blase K, Friedman R, Wallace F. Implementation Research: A Synthesis of the Literature Dean L. Fixsen; 2005.

7. Kim JY. "Within Our Grasp: A World Free of Poverty" Speech at Georgetown University; 2013.

8. Glasgow RE, Chambers D. Developing robust, sustainable, implementation systems using rigorous, rapid and relevant science. Clin Transl Sci 2012; 5(1): 48-55.

9. Rabin BA, Brownson RC, Haire-Joshu D, Kreuter MW, Weaver NL. A glossary for dissemination and implementation research in health. J Public Health Manag Pract 2008; 14(2): 117-23.

10. Odeny TA, Padian N, Doherty MC, et al. Definitions of implementation science in HIV/AIDS. Lancet HIV 2015; 2(5): e178-80.

11. Kim JY, Farmer P, Porter ME. Redefining global health-care delivery. Lancet 2013; 382(9897): 1060-9.

12. Blanchard JF, Aral SO. Program Science: an initiative to improve the planning, implementation and evaluation of HIV/sexually transmitted infection prevention programmes. Sex Transm Infect 2011; 87(1): 2-3.

13. Damschroder LJ, Aron DC, Keith RE, Kirsh SR, Alexander JA, Lowery JC. Fostering implementation of health services research findings into practice: a consolidated framework for advancing implementation science. Implement Sci 2009; 4: 50.

14. Network NIR. Active Implementation Frameworks. https://implementation.fpg.unc.edu/ (accessed June 24 2018).

15. Meyers DC, Durlak JA, Wandersman A. The quality implementation framework: a synthesis of critical steps in the implementation process. Am J Community Psychol 2012; 50(34): 462-80.

16. Tabak RG, Khoong EC, Chambers DA, Brownson RC. Bridging research and practice: models for dissemination and implementation research. Am J Prev Med 2012; 43(3): 337-50.

17. Peters D, Tran, NT, Adam, T. . Implementation Research in Health: A Practical Guide. World Health Organization 2013; Geneva: World Health Organization.

18. Pinnock H, Barwick M, Carpenter CR, et al. Standards for Reporting Implementation Studies (StaRI) Statement. BMJ 2017; 356: i6795.

19. Peters DH, Noor AA, Singh LP, Kakar FK, Hansen PM, Burnham G. A balanced scorecard for health services in Afghanistan. Bull World Health Organ 2007; 85(2): 146-51.

20. Foege WH, Millar JD, Lane JM. Selective epidemiologic control in smallpox eradication. Am J Epidemiol 1971; 94(4): 311-5. 
21. Henao-Restrepo AM, Longini IM, Egger M, et al. Efficacy and effectiveness of an rVSVvectored vaccine expressing Ebola surface glycoprotein: interim results from the Guinea ring vaccination cluster-randomised trial. Lancet 2015; 386(9996): 857-66.

22. Baqui AH, Saha SK, Ahmed AS, et al. Safety and efficacy of alternative antibiotic regimens compared with 7 day injectable procaine benzylpenicillin and gentamicin for outpatient treatment of neonates and young infants with clinical signs of severe infection when referral is not possible: a randomised, open-label, equivalence trial. Lancet Glob Health 2015; 3(5): e27987.

23. Trial ANS, Tshefu A, Lokangaka A, et al. Simplified antibiotic regimens compared with injectable procaine benzylpenicillin plus gentamicin for treatment of neonates and young infants with clinical signs of possible serious bacterial infection when referral is not possible: a randomised, open-label, equivalence trial. Lancet 2015; 385(9979): 1767-76.

24. WHO. Guideline: Managing possible serious bacterial infection in young infants when referral is not feasible 2015.

25. Esamai F, Tshefu AK, Ayede AI, et al. Ongoing trials of simplified antibiotic regimens for the treatment of serious infections in young infants in South Asia and sub-Saharan Africa: implications for policy. Pediatr Infect Dis J 2013; 32 Suppl 1: S46-9.

26. Qazi SA, Wall S, Brandes N, Engmann C, Darmstadt GL, Bahl R. An innovative multipartner research program to address detection, assessment and treatment of neonatal infections in low-resource settings. Pediatr Infect Dis J 2013; 32 Suppl 1: S3-6.

27. Adjei S GJ. Evolution of Health Research Essential for Development in Ghana. Council on Health Research for Development. COHRED Document 9931999.

28. Awoonor-Williams JK, Bawah AA, Nyonator FK, et al. The Ghana essential health interventions program: a plausibility trial of the impact of health systems strengthening on maternal \& child survival. BMC Health Serv Res 2013; 13 Suppl 2: S3.

29. Report GN. Actions and Accountability to Advance Nutrition and Sustainable Development, 2015.

30. Hansen PM, Peters DH, Niayesh H, Singh LP, Dwivedi V, Burnham G. Measuring and managing progress in the establishment of basic health services: the Afghanistan health sector balanced scorecard. Int J Health Plann Manage 2008; 23(2): 107-17.

31. Peters DH WB, ebrary Inc. Improving health service delivery in developing countries from evidence to action. Washington, DC: World Bank, xxii, 338 p 2009.

32. Steinhardt LC, Aman I, Pakzad I, Kumar B, Singh LP, Peters DH. Removing user fees for basic health services: a pilot study and national roll-out in Afghanistan. Health Policy Plan 2011; 26 Suppl 2: ii92-103.

33. Engineer CY, Dale E, Agarwal A, et al. Effectiveness of a pay-for-performance intervention to improve maternal and child health services in Afghanistan: a cluster-randomized trial. Int J Epidemiol 2016; 45(2): 451-9.

34. Black RE, Victora CG, Walker SP, et al. Maternal and child undernutrition and overweight in low-income and middle-income countries. Lancet 2013; 382(9890): 427-51.

35. WHO. Fifty Fourth World Health Assembley: Infant and Child Nutrition. Geneva, Switzerland. 2001.

36. United Nations Zero Hunger Challenge. 2016.

37. United Nations General Assembly adopts resolution on SDGs report. 2014.

38. Nutrition for Growth. Beating Hunger Through Business and Science.

39. Sun Movement Scaling up nutrition, 2015. 
40. Gillespie S, Haddad L, Mannar V, et al. The politics of reducing malnutrition: building commitment and accelerating progress. Lancet 2013; 382(9891): 552-69.

41. LTD M. Independent Comprehensive Evaluation of the Scaling Up Nutrition Movement; Oxford UK. 2015.

42. Pelletier D, Gervais S, Hafeez-Ur-Rehman H, Sanou D, Tumwine J. Boundary-spanning actors in complex adaptive governance systems: The case of multisectoral nutrition. Int J Health Plann Manage 2018; 33(1): e293-e319.

43. Martineau T, Raven J, Aikins M, et al. Strengthening health district management competencies in Ghana, Tanzania and Uganda: lessons from using action research to improve health workforce performance. BMJ Glob Health 2018; 3(2): e000619.

44. EXPANDNET. Practical guidance for scaling up health service innovations. Geneva: World Health Organization. 2009.

45. EXPANDNET. Nine Steps for Developing a Scale-Up Strategy. Geneva: World Health Organization. 2010.

46. Baral S, Subedi, H.M, Paudel, P., Chand, P.B, Shrestha, M.P, McCullough, A. Raven, J. Theobald, S. Martineau, T. Elsey, H. Implementation research to assess a health workers performance-based management system in Nepal Acta Paediatrica 2018; In press.

47. Prytherch H WK, Alonso-Garbayo A, et al. Supporting decentralised management to improve health workforce performance - PERFORM. Geneva: Switzerland: Health Systems Alliance, WHO 2016.

48. HERD. Supporting district health managers in Nepal to improve health workers' performance. 2016.

49. Gilson L, Elloker S, Olckers P, Lehmann U. Advancing the application of systems thinking in health: South African examples of a leadership of sensemaking for primary health care. Health Res Policy Syst 2014; 12: 30.

50. Kernick D. Facilitating resource decision making in public organizations drawing upon insights from complexity theory. Emergence: Complexity and Organization 2005; Mar 31. 51. Health information data Mitchell Plain Sub-district 2011-2014.

52. Cleary S SN, Botes E, Figlan N, Lehmann U, Gilson L. Re-imagining community participation at the district level: Lessons from the DIALHS collaboration. Durban, SA: Health Systems Trust 2015.

53. Raven J, Baral S, Wurie H, et al. What adaptation to research is needed following crises: a comparative, qualitative study of the health workforce in Sierra Leone and Nepal. Health Res Policy Syst 2018; 16(1): 6.

54. Bohren MA, Vogel JP, Hunter EC, et al. The Mistreatment of Women during Childbirth in Health Facilities Globally: A Mixed-Methods Systematic Review. PLoS Med 2015; 12(6): e1001847; discussion e.

55. McMahon SA, George AS, Chebet JJ, Mosha IH, Mpembeni RN, Winch PJ. Experiences of and responses to disrespectful maternity care and abuse during childbirth; a qualitative study with women and men in Morogoro Region, Tanzania. BMC Pregnancy Childbirth 2014; 14: 268. 56. Warren C, Njuki R, Abuya T, et al. Study protocol for promoting respectful maternity care initiative to assess, measure and design interventions to reduce disrespect and abuse during childbirth in Kenya. BMC Pregnancy Childbirth 2013; 13: 21.

57. Abuya T, Ndwiga C, Ritter J, et al. The effect of a multi-component intervention on disrespect and abuse during childbirth in Kenya. BMC Pregnancy Childbirth 2015; 15: 224. 
58. Amouzou A, Morris S, Moulton LH, Mukanga D. Assessing the impact of integrated community case management (iCCM) programs on child mortality: Review of early results and lessons learned in sub-Saharan Africa. J Glob Health 2014; 4(2): 020411.

59. Hamer DH, Marsh DR, Peterson S, Pagnoni F. Integrated community case management: next steps in addressing the implementation research agenda. Am J Trop Med Hyg 2012; 87(5 Suppl): 151-3.

60. Rasanathan K, Muniz M, Bakshi S, et al. Community case management of childhood illness in sub-Saharan Africa - findings from a cross-sectional survey on policy and implementation. J Glob Health 2014; 4(2): 020401.

61. Marchal B. DE, Dedzo M., De Brouwere V, Kegels G. Decentralisation, decision spaces and human resource management at hospital level. High commitment human resource management approaches used by the management team of Ghana's Cape Coast Central Regional Hospital. Antwerp: Belgium: Institute of Tropical Medicine 2005.

62. George A, Rodriguez DC, Rasanathan K, Brandes N, Bennett S. iCCM policy analysis: strategic contributions to understanding its character, design and scale up in sub-Saharan Africa. Health Policy Plan 2015; 30 Suppl 2: ii3-ii11.

63. Bennett S, Dalglish SL, Juma PA, Rodriguez DC. Altogether now... understanding the role of international organizations in iCCM policy transfer. Health Policy Plan 2015; 30 Suppl 2: ii26-ii35.

64. Rodriguez DC, Shearer J, Mariano AR, Juma PA, Dalglish SL, Bennett S. Evidenceinformed policymaking in practice: country-level examples of use of evidence for iCCM policy. Health Policy Plan 2015; 30 Suppl 2: ii36-ii45.

65. Rasanathan K. Policy analysis--important for improving iCCM implementation; essential for success of global health efforts. Health Policy Plan 2015; 30 Suppl 2: ii1-ii2.

66. Rau B. The Avahan-India AIDS Initiative: Promising Approaches to Combination HIV Prevention Programming in Concentrated Epidemics. Case Study Series. In: Inc JS, editor Arlington, USA: USAID 2011.

67. Kumar R, Mehendale SM, Panda S, et al. Impact of targeted interventions on heterosexual transmission of HIV in India. BMC Public Health 2011; 11: 549.

68. Boussinesq M, Gardon J, Gardon-Wendel N, Chippaux JP. Clinical picture, epidemiology and outcome of Loa-associated serious adverse events related to mass ivermectin treatment of onchocerciasis in Cameroon. Filaria J 2003; 2 Suppl 1: S4.

69. Turner JD, Tendongfor N, Esum M, et al. Macrofilaricidal activity after doxycycline only treatment of Onchocerca volvulus in an area of Loa loa co-endemicity: a randomized controlled trial. PLoS Negl Trop Dis 2010; 4(4): e660.

70. Ovretveit J SB PD, Thota A, El-Saharty S. Review of Strategies to Strengthen Health Services. . In: Peters D H E-SS SB, Janovsky K, Vujicic M, ed. Improving Health Services in Developing Countries: From Evidence to Action. Washington DC: World Bank; 2009.

71. Begum J ZB, Dooley K. Advances in Health Care Organization Theory. San Francisco: Jossey-Bass 2003.

72. El-Saharty S, Nagaraj, B. A. Reducing the Risk of HIV/AIDS among Female Sex Workers in India. The Global Delivery Initiative, The World Bank 2015.

73. Brieger WR, Sommerfeld JU, Amazigo UV, Network CDI. The Potential for Community-Directed Interventions: Reaching Underserved Populations in Africa. Int $Q$ Community Health Educ 2015; 35(4): 295-316. 
74. Katabarwa MN, Habomugisha P, Eyamba A, et al. Community-directed interventions are practical and effective in low-resource communities: experience of ivermectin treatment for onchocerciasis control in Cameroon and Uganda, 2004-2010. Int Health 2016; 8(2): 116-23. 75. Alley WS, van Oortmarssen GJ, Boatin BA, et al. Macrofilaricides and onchocerciasis control, mathematical modelling of the prospects for elimination. BMC Public Health 2001; 1: 12.

76. Winnen M, Plaisier AP, Alley ES, et al. Can ivermectin mass treatments eliminate onchocerciasis in Africa? Bull World Health Organ 2002; 80(5): 384-91.

77. Hoerauf A, Specht S, Marfo-Debrekyei Y, et al. Efficacy of 5-week doxycycline treatment on adult Onchocerca volvulus. Parasitol Res 2009; 104(2): 437-47.

78. Grol RP, Bosch MC, Hulscher ME, Eccles MP, Wensing M. Planning and studying improvement in patient care: the use of theoretical perspectives. Milbank $Q$ 2007; 85(1): 93-138. 79. Chambers DA, Glasgow RE, Stange KC. The dynamic sustainability framework: addressing the paradox of sustainment amid ongoing change. Implement Sci 2013; 8: 117.

80. Zwarenstein M, Treweek S, Gagnier JJ, et al. Improving the reporting of pragmatic trials: an extension of the CONSORT statement. BMJ 2008; 337: a2390. 